\title{
Trypsin loss at the ileum of calves fed milk replacers containing legume protein
}

\author{
JP Lallès, R Toullec
}

INRA, Laboratoire du Jeune Ruminant, 65, rue de Saint-Brieuc, 35042 Rennes cedex, France

Two experiments were conducted on 6 and 5 2-3-month-old calves fitted with a re-entrant ileal cannula (table I). Calves were fed 58-60 gDM/ $\mathrm{kg}$. $75 / \mathrm{d}$ of milk substitute diets containing 22 (exp 1) or $25 \%(\exp 2)$ crude protein (\%DM). Skim milk powder (SMP) was the only protein source or was partly $(50 \%$ in exp $1 ; 34 \%$ in exp 2$)$ replaced by either soybean products (antigenic ASP or non-antigenic NASP, exp 1) or a raw spring pea flour (exp 2). Diets were given for 2 and 4 weeks in exp 1 and 2, respectively. Ileal digesta were collected over 4 d during week 1 (exp 2, pea week $1), 2(\exp 1)$ and $4(\exp 2$, pea week 4). Trypsin activity was determined using $N$-benzoyl-DL-arginine-para-nitroanilide as substrate.

The level of trypsin in ileal digesta was unaffected by protein source (table I). In exp 1, this was also true for its daily flow. In contrast, raw pea led to an increase in ileal flow of digesta and subsequently trypsin after 1 and 4 weeks $(P<$ 0.05 ) of treatment. Our results show that soybean protein source per se did not modify the ileal flow of enzyme, as already shown for SMP, soybean and fish protein (Ternouth et al, 1976). With the raw pea used in exp 2, an immune reac- tion leading to a decrease in both apparent protein digestibility and true digestion of pea legumin was observed (Bush et al, 1992). Present data indicate that the former also resulted from an increased loss of endogenous protein. Trypsin digestion in the small intestine is apparently rather low since its secretion was found to be 20-25

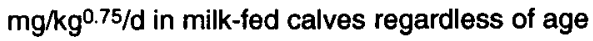
(Ternouth et al, 1976). Moreover, this secretion is probably stimulated during calf sensitization to antigenic protein as indicated by results from exp 2 , although a direct effect of trypsin inhibitors from pea cannot be excluded. Trypsin may be totally degraded in the lower gut since it was not detected in the faeces of intact calves.

in conclusion, ileal loss of trypsin was unaffected by soybean protein fed for 2 weeks but greatly increased after 1 and 4 weeks of raw pea consumption.

Bush RS, Toullec R, Caugant I, Guilloteau P (1992) J Dairy Sci 75, 3539-3552

Ternouth JH, Roy JHB, Shotton S (1976) Br J Nutr 36, 523-535

Table I. Trypsin level and daily flow at the ileum of preruminant calves.

\begin{tabular}{|c|c|c|c|c|c|c|c|c|}
\hline \multirow[t]{2}{*}{ Variable } & \multicolumn{4}{|c|}{ Experiment $1(\mathrm{n}=6)$} & \multicolumn{4}{|c|}{ Experiment $2(\mathrm{n}=5)$} \\
\hline & $S M P 1$ & $A S P$ & NASP & $(S E)$ & $S M P 2$ & Pea week 1 & Pea week 4 & (SE) \\
\hline Level (mg/gDM) & 4.51 & 3.63 & 3.40 & $(0.43)$ & 4.18 & 4.74 & 4.74 & $(0.26)$ \\
\hline Flow $(\mathrm{g})$ & 1.25 & 1.53 & 1.58 & $(0.24)$ & 0.64 & 1.70 & $2.79^{*}$ & $(0.31)$ \\
\hline Flow (mg/kg0.75) & 32.0 & 40.2 & 42.0 & $(6.47)$ & 16.1 & 51.4 & $85.2^{*}$ & (9.67) \\
\hline
\end{tabular}

" Different from SMP2 $(P<0.05)$. 